\title{
Fossil protists and fungi in amber and rock substrates
}

\author{
Carmen Ascaso $^{1}$, Jacek Wierzchos ${ }^{2}$, Mariela Speranza ${ }^{3}$, Juan Carlos Gutiérrez ${ }^{4}$, \\ Ana Martín González ${ }^{4}$, Asuncion de los Ríos ${ }^{1}$, and Jesús Alonso ${ }^{5}$ \\ ${ }^{1}$ Centro de Ciencias Medioambientales, CSIC, Serrano 115 bis, 28006 Madrid, Spain \\ email: ascaso@ccma.csic.es \\ ${ }^{2}$ Servicio de Microscopía Electrónica, Universidad de Lleida, Rovira Roure 44, 25198 Lleida, Spain \\ ${ }^{3}$ Laboratorio de Micologia, Facultad de Ciencias, Universidad de la República, \\ Julio Herrera y Reissig 565, 11400 Montevideo, Uruguay \\ ${ }^{4}$ Departamento de Microbiologia III, Facultad de Biología, Universidad Complutense, 28040 Madrid, Spain \\ ${ }^{5}$ Museo de Ciencias Naturales de Álava, C/ Siervas de Jesús 24, 01001 Vitoria-Gasteiz, Spain
}

\begin{abstract}
The present study was designed to gain insight into the protists and fungi that made up the microbiota in the past, fossilized in two different substrates: amber and sandstone. The amber, dated as Lower Cretaceous, was from Álava in northern Spain, while fossil-bearing sandstone rocks were collected from the Linnaeus terrace and Mount Fleming regions of Antarctica. When examining this type of inclusion in hard substrates, it first has to be established whether the microorganism is mummified or only partially mineralized. In the latter case, some of the organism's autofluorescence may be preserved. In our amber samples, light microscopy revealed a very well preserved microcenosis in what must have been a semiaquatic habitat comprised of several types of protozoa including Amoeba, Paramecium and Astasia (Euglena), Amebas limax and the colpodid ciliate Pseudoplatyophrya nana, as well as an abundant fossilized mycelium. The SEM-BSE procedure provided us with ultrastructural details of the fungi and protozoa, especially amoebae and flagellates. In the sandstone samples from Linnaeus terrace, it was possible to identify presumptive diatoms. Ultrastructural details were well-preserved in a fossil Trebouxia-type microalga from Mount Flemming, including the inner chloroplast area normally occupied by the pyrenoid. This fossilized microalga was shown by energy dispersive spectroscopy (EDS) to contain high Si levels in the pyrenoid zone, and high Fe levels in the area corresponding to the chloroplast periphery, peripheric cytoplasm and cell wall. In sandstone from Linnaeus Terrace, fossilized algae showed no central core containing Si, and the entire cell appeared to be completely filled with $\mathrm{Al}$, $\mathrm{K}$ and $\mathrm{Fe}$, with $\mathrm{Fe}$ most intensely observed within the algal wall.The present observations suggest that a well-preserved cell ultrastructure is the best criterion of biogenicity.
\end{abstract}

\section{INTRODUCTION}

The term biocomplexity has been recently used with reference to the study of an ecosystem at the highest level. When examining an ecosystem on a scale as small as hundreds of cubic microns, all its components need to be analysed at the microscale level. Analysis of the components of microcenoses in translucent resins such as amber can reveal the components and possible functioning of certain microecosystems in the past. The finding of fossilized microorganisms in lithic substrates has helped us reconstruct the biotic and abiotic elements of these microecosystems before the appropriate conditions for permineralization of the microbiota were reached, also millions of years ago (e.g., Ascaso and Wierzchos 2003).

In some regions of Antarctica, certain microorganisms are presently able to survive its extremely cold and dry conditions. Microbial ecology studies of the living microorganisms in the Dry Valley area of the Ross Desert commenced almost 30 years ago, yet investigations on fossilized microbiota have only very recently got underway (Wierzchos and Ascaso 2001). Careful interpretation of the morphological features of fossilized cells, such as preserved cell walls in algae, fungi and bacteria, cytoplasm elements such as chloroplast membranes in algae and the spatial context of these structures enabled their identification as cryotoendolithic microfossils (Wierzchos and Ascaso 2002). In later studies, biomarkers of Antarctic microorganism fossils were detected. These biomarkers - traces left behind by microorganisms after their death - are the result of the biological activity of these endolithic microorganisms while they were still alive. Fe rich diagenetic minerals in the form of iron hydroxide nanocrystals and biogenic clays are deposited around endolithic hyphae (Wierzchos et al. 2003). Biomarkers in the form of physicochemical weathering patterns and calcium oxalate and silica deposits have also been detected in pieces of granite rock from the Antarctic Ross Sea coast (Ascaso and Wierzchos 2003).

Both in geological and palaeontological terms, amber from Álava (N Spain) is considered exceptional (see Alonso et al. 2000). Along with Lebanese amber (Schlee and Dietrich 1970) and the recently uncovered amber from Charente-Maritime, France (Néraudeau et al. 2002), this is one of the only three known highly fossiliferous amber deposits of the Lower Cretaceous. According to Alonso et al. (2000), this amber was deposited in areas of a distal fluvial environment, where stagnant waters allowed the formation of lignite and pyrite nodules. Studies on microbiota inclusions in amber started with those by Poinar (1992) and Wier et al. (2002) using transmission electron microscopy (TEM), by Kohring (1995) using scanning electron microscopy with secondary electron imaging (SEM-SE), and by Waggoner (1994) and Schönborn et al. (1999) using light microscopy (LM). Recently, Grimaldi used SEM in secondary electron mode to examine inclusions in amber mainly composed of wood, and fragments of insects (Grimaldi 2000a; 2000b). Cano and Boruki (1995) even purportedly revived and identified Bacillus bacteria in amber from the Dominican Republic. Lambert et al. (1998) were also able to isolate a Staphylococcus species from soil and plant fragments embedded in 
amber. Further, some authors have argued that DNA is preserved in amber (Smith and Austin 1997, Stankiewicz et al. 1998). Several genera of fungi have been described by different authors using LM. Thus, there are descriptions of Aspergillus and Entomophtoralean species and higher fungi fossilized in amber from the Dominican Republic (Thomas and Poinar 1988; Poinar and Thomas 1982; Poinar and Singer 1990; Rikkinen and Poinar 2001). Protozoa have also been identified in amber (Poinar 1992; Waggoner 1994; Schönborn et al. 1999). Ascaso et al. (2003) combined several innovative microscopy techniques for the in depth ultrastructural analysis of the components of the microbiota preserved in amber from Álava. This allowed them to observe the 3-dimensional structure of the microcenosis and to simultaneously discern which parts of the protist and fungal structures were most mineralized. Scanning electron microscopy with backscattered electron imaging (SEM-BSE) was one of the techniques applied.

Although fungi are an extremely diverse group of microorganisms, only around one hundred fossilized fungi and very few genera have been identified in fossil resins (Pirozynski 1976; Rikkinen and Poinar 2001). In lithic substrates, fossilized fungi were first, and very recently, described in the Antarctic sandstones of Mount Flemming in the Ross Desert (McMurdo Dry Valleys) (Wierzchos and Ascaso 2002; Ascaso and Wierzchos 2003). These fungi were observed alongside accompanying fossil microalgae (protists).

The study of fungi and protists fossilized in amber and Antarctic rock substrates could contribute to the field of microbial ecology, since the micropalaeontological data obtained will help gain insight into the evolution of these microecosystems.

The aim of the present study was to analyse the protists and fungi fossilized in amber and Antarctic rocks that made up the microbiota in the past, and also to try to improve our understanding of permineralization phenomena by determining the chemical elements present in the microbiota at the nanoscale.

\section{MATERIALS}

\section{Amber}

Amber collection and preparation. For details of the collection and preparation of amber deposits dated as Lower Cretaceous, see Corral et al. (1999). Detailed references on the macroscopic inclusions observed by other authors in these deposits and a description of the techniques used to observe microcenoses and microdebris (plant and animal remnants) can be found in Ascaso et al. (2003).

\section{Lithic Substrate}

Pieces of sandstone rock thought to contain fossils were collected by E. I. Friedmann over the year 1983/84 from the Linnaeus Terrace region $\left(77.60^{\circ} \mathrm{S}, 161.08^{\circ} \mathrm{E}, 1600 \mathrm{~m}\right.$ a.s.l) of the Ross Desert. Mean annual air temperature in 1993 was reported as $-23.2^{\circ} \mathrm{C}$ for this area (Friedmann et al. 1994). Further sandstone samples were collected from the harsh Mount Fleming region $\left(77^{\circ} 33^{\prime} \mathrm{S}, 160^{\circ} 06^{\prime} \mathrm{E}, 2200 \mathrm{~m}\right.$ alt.) of the Ross Desert, where the mean annual air temperature in 1993 was $-24.9^{\circ} \mathrm{C}$ (Friedmann et al., 1994). The rocks were air-dried, and stored in an air-conditioned room until use.

\section{METHODS}

When examining fossil protists and fungi included in hard substrates, one has to dispense of all molecular techniques and apply the more suitable methods of confocal and electron microscopy. It also has to be considered whether the microorganism is mummified or only partially mineralized. In the latter case, some of the organism's autofluorescence may be preserved, as in some protists and fungi found in amber. The protists and fungi fossilized in Antarctic rocks examined here, were fully mineralized such that they emit no autofluorescence.

Despite its lower power of resolution, light microscopy may be used for a preliminary view of the microorganisms mummified or mineralized in the amber and should also be used to classify

\section{TEXT-FIGURE 1}

a Fossilized hyaline mycelium found in amber; scale bar $=50 \mu \mathrm{m}$.

b Closer view of the fungal colony composed by coenocytic hyphae. Most hyphae are $0.75-1 \mu \mathrm{m}$ wider and few bifurcates branches were found at the expanding mycelium zone. Note the abundant vesicles spore-like structures in the hyphae. Other fungal remnants can also detected in the sample; scale bar = $20 \mu \mathrm{m}$.

c A dark mycelium was detected in the border zone of the amber sample, which strongly resemble a saprophytic fungus; scale bar $=50 \mu \mathrm{m}$.

d Dark mycelium comprised of thick-walled vegetative hyphae, 1.5 to $3 \mu \mathrm{m}$ in width, with numerous simple clam connections and no septa (black arrow); scale bar $=20 \mu \mathrm{m}$. e Globose and irregularly constricted cystidia like structures are best observed by fluorescence microscopy (white arrow). Simple clamp connectios marked by black arrow; scale bar $=20 \mu \mathrm{m}$.

f Simple clamp connections (black arrows); scale bar = $20 \mu \mathrm{m}$.

g Long apical hyphae with irregular surface and encrusted material resembled gloeocystidia forms presents in present-day Basidiomycetes (black arrow); scale bar $=20 \mu \mathrm{m}$.

h Hyphae segments were produce by constriction and refractive intercalary structure are present (black arrows); scale bar $=20 \mu \mathrm{m}$. 

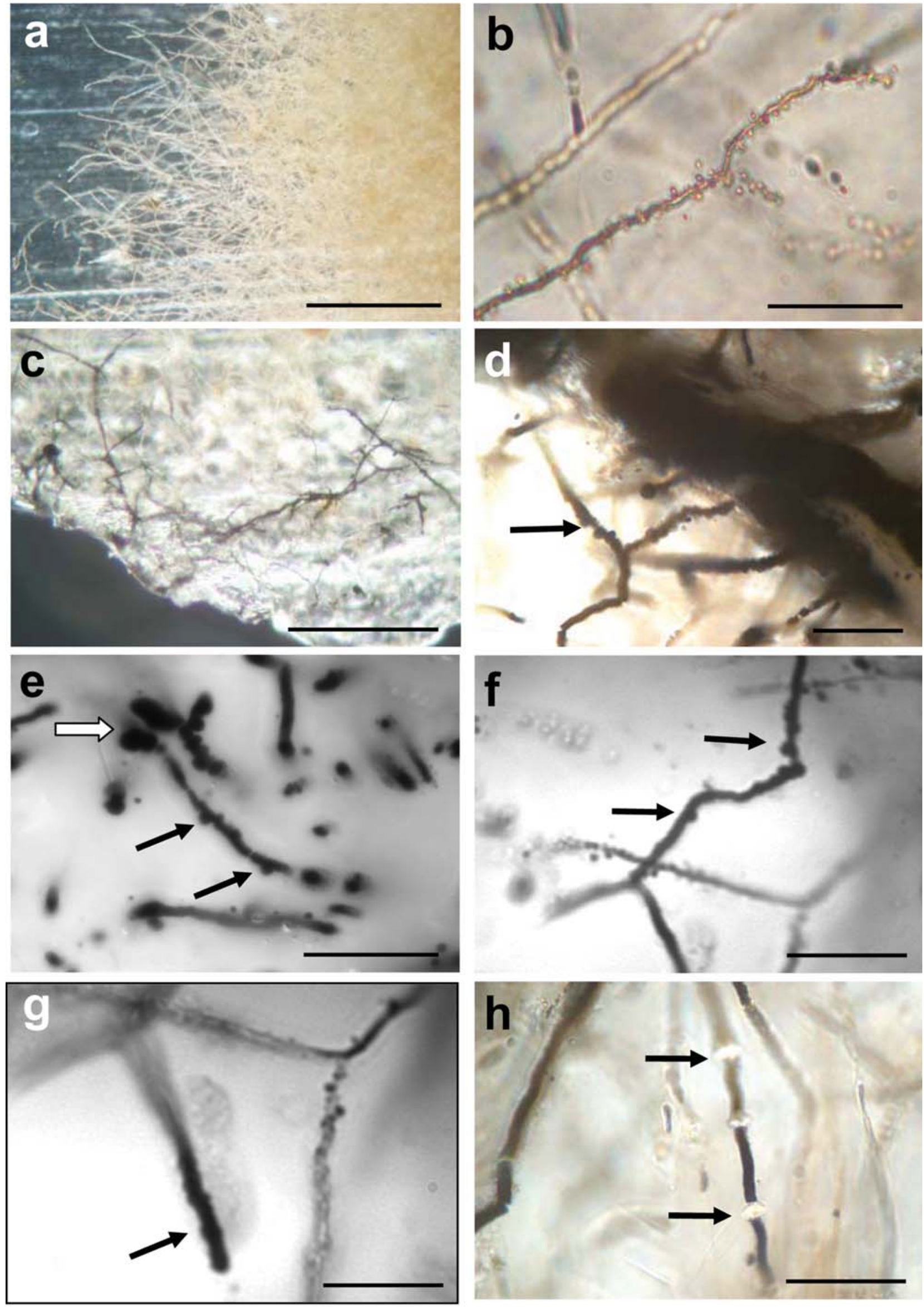
them. The taxonomy of current protists and fungi is based on decades of LM work, though molecular methods are now being extensively used, mainly for fungi. Light microscopy has also been widely applied to the study of arthropods in amber, although it is much more difficult to examine microorganisms such as amoebae, ciliates, flagellates and fungi in this resin. Thus, in this study, we used LM, SEM-BSE and confocal laser scanning microscopy (CLSM) for the fossil protists and fungi in amber, and SEM-BSE with energy dispersive spectroscopy (EDS) to observe and chemically characterise these microorganisms mineralized in Antarctic rocks.

-LM. Amber samples for LM were screened under a Zeiss Axioskop 2 Microscope. Some of the specimens were simultaneously examined under a fluorescence microscope (Zeiss Axioplan) with ultraviolet light using a 360/40D filter. The fluorescence emitted was analysed through a $460 \mathrm{~nm}$ barrier filter, and the image was captured with a CCD device (Photometrics CH250/A).

These samples were also subjected to CLSM.

CLSM. This technique has great advantages for the study of mummified microorganisms embedded in hard, translucent substrates, and was therefore used here to examine inclusions in amber. The polished blocks of amber were mounted on microscope slides using double-sided adhesive tape, and observed using a LSM 310 Zeiss confocal microscope with a Plan-Apochromat 63x/1.40 oil immersion objective. Argon $(488 \mathrm{~nm})$ and helium/neon $(543 \mathrm{~nm})$ lasers were used to generate an excitation beam. The resultant emission was filtered through long pass filters of $>515 \mathrm{~nm}$ and $>575 \mathrm{~nm}$, respectively. The relatively good translucency of the amber permits the three-dimensional (3D) reconstruction of fungal and protozoan colonies and gives an idea of their spatial organization. To obtain this information, stacks of 20-30 single confocal optical sections (vertical $(\mathrm{z})$ resolution about $0.6 \mu \mathrm{m}$ ) images are prepared at $0.5-1 \mu \mathrm{m}$ intervals through the sample and digitally stored and compiled.

CLSM has been successfully used for the study of live lithic microbiota (Rautureau at al. 1993; Ascaso et al. 1998; Wierzchos and Ascaso 2001). However, this method cannot be applied to the study of microorganisms embedded in what was in the past an organo-mineral phase, if the biological components (algae, fungi, etc.) are presently completely mineralized.
$S E M-B S E$. Both for the analysis of partly or fully mineralized microorganisms in amber and mineralized microorganisms embedded in a lithic substrate, SEM-BSE has proved to be the most appropriate. When used to examine specimens in amber, SEM-BSE reveals the structural details of protists and fungi. This is of particular interest, since these details may be compared with the inner structure of present-day protists observed using the transmission electron microscope. If the microorganism is mineralized in rock, SEM-BSE is the only method currently known to reveal a large number of ultrastructural details. These details allow the identification of the fossilized organism.

The use of backscattered electrons in SEM yields high magnification images and contrast attributable to differences in the average atomic number of the target (Joy 1991). The partial or total mineralization of microorganisms in amber induces differences in atomic number that reveal the ultrastructure of the microorganism. When examining lithic materials containing fully mineralized fossils, complete mineralization also gives rise to atomic number differences that eventually reflect the ultrastructure of the microorganism.

For the present SEM-BSE observations and/or EDS microanalyses, the amber and lithic fragments were embedded in epoxy resin. After polymerization, the blocks were cut and finely polished (e.g., Wierzchos and Ascaso 1994). Transverse sections of polished surfaces were carbon-coated and examined using a DSM 940 A Zeiss and a DSM 960 A Zeiss microscope (both equipped with a four-diode, semiconductor BSE detector and a Link ISIS microanalytical EDS system). SEM-BSE and EDS examinations of the samples were simultaneously performed. The microscope operating conditions were as follows: $0^{\circ}$ tilt angle, $35^{\circ}$ take-off angle, $15 \mathrm{kV}$ acceleration potential, 6 or $25 \mathrm{~mm}$ working distance and 1-5 nA specimen current.

\section{RESULTS}

\section{Amber}

Light microscopy revealed a very well preserved microcenosis in, what was in the past, a semiaquatic habitat comprised of several types of protozoa and an abundant fossilized mycelium. Text-figure 1a-b shows a mycelia mat formed by hyaline hyphae with many vesicle structures. Most hyphae were 0.75-1 ìm wide, and only a few bifurcated branches were found in the region of the expanding mycelium. No septa were observed, the hyphal system appearing to be coenocytic. The vesicle struc-

\section{TEXT-FIGURE 2}

a LM image of an amoeboid protozoa, probably of the genus Amoeba. Arrows indicate pseudopodia; scale bar $=50 \mu \mathrm{m}$.

b LM image of a ciliated, paramecium-like protozoa. Arrow indicates oral groove; scale bar $=50 \mu \mathrm{m}$;

c Image of a single CLSM section showing a protozoa (arrows) and hyphae (arrowheads) cells; scale bar = $50 \mu \mathrm{m}$. d Image of single CLSM section showing a protozoa (arrow); scale bar $=50 \mu \mathrm{m}$.

e Image of single CLSM section showing a protozoa; scale bar $=50 \mu \mathrm{m}$.

f 3D reconstruction (15 single CLSM sections separated by $1 \mu \mathrm{m}$ ) of protozoa cells. Stereo image; scale bar $=50 \mu \mathrm{m}$. 

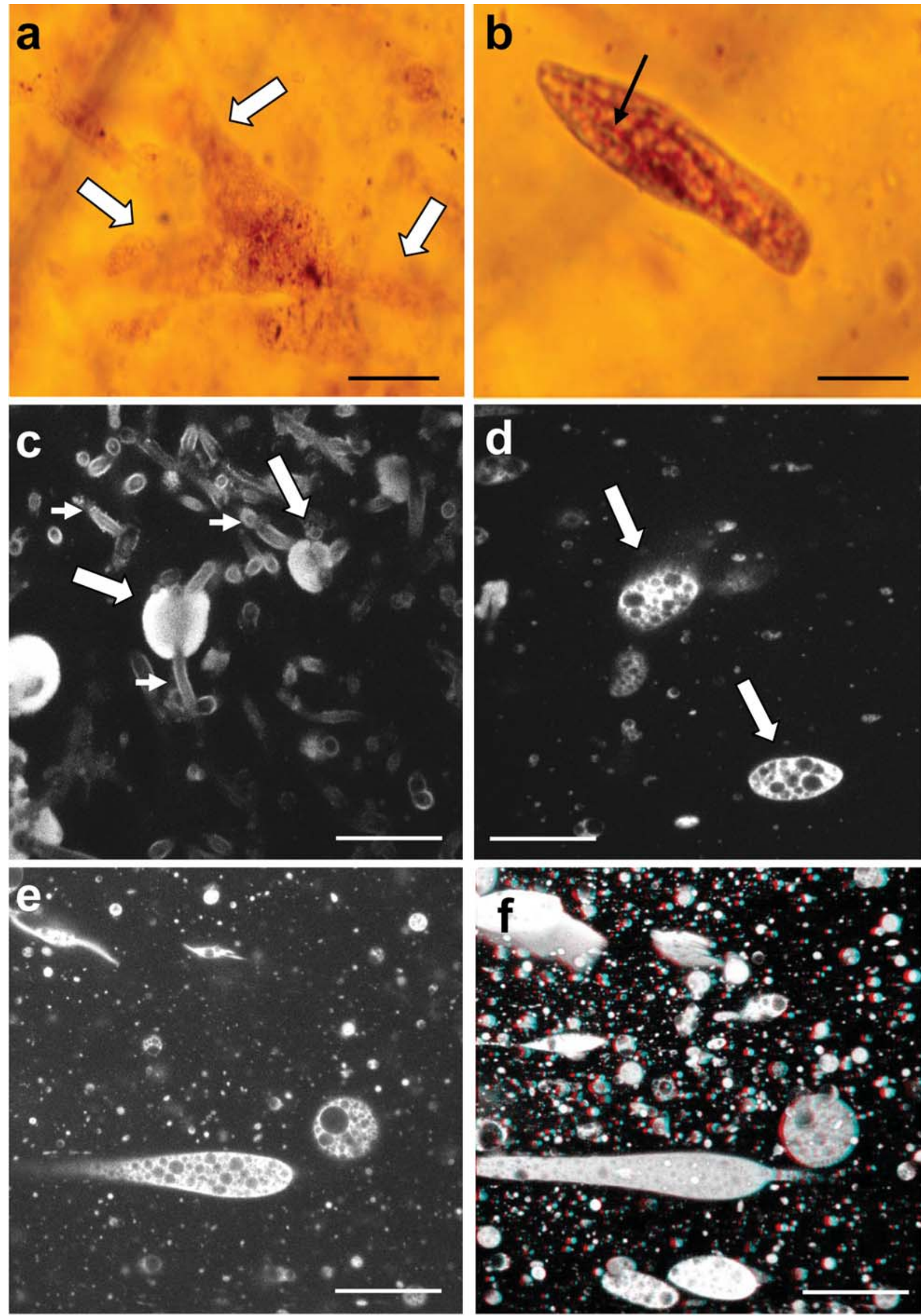
tures were closely associated with hyphae and resembled fungal spores.

Given the low resolution of LM and the refractive properties of the amber, a detailed description of the hyphae and spore-like structures could not be made and it was not possible to determine hyphal wall thicknesses.

Besides the many fungal structures observed in the amber sample, a distinct dark fungal colony was detected (text-fig. 1c). This dark extensive mycelium appeared in the border zone of the amber piece, comprised of thick-walled vegetative hyphae 1.5-3 $\mu \mathrm{m}$ in width (text-fig. 1d). Most of these hyphae had irregular surfaces and some appeared to have a septum but we could not determine whether this was an artefact of fossilization (text-figs. 1d,e). However, numerous simple clamp connections resembling those of living basidiomycetes were observed (text-figs. 1d-f, arrows). The use of fluorescence microscopy on the same specimen improved visualization of the mummified dark mycelium structures, and globose, sometimes irregularly constricted cystidia-like structures were observed (text-fig. 1e, white arrow). In addition, long apical hyphae with irregular surfaces and encrusted material resembling gloeocystidia shapes could be seen (text-fig. 1g). Few terminal bifurcated branches were detected (text-fig. 1f). Hyphal segments were produced by constriction and the presence of refractive intercalary structures was noted (text-fig. 1h, arrows). All these structures occur in present-day basidiomycetes.

Text-figure 2 shows both LM (text-figs. 2 a,b) and CLSM (text-figs. 2 c-f) images. Text-figure $2 \mathrm{a}$ is an LM image of an Amoeba showing several pseudopods (arrows indicate pseudopodia). Text-figure $2 \mathrm{~b}$ shows a ciliate, probably of the genus Paramecium. In text-figure $2 \mathrm{c}$, the fungal cells (arrowhead) accompany the protozoan (arrows), as shown in a confocal simple section. Text-figures $2 \mathrm{~d}-\mathrm{f}$ only show protozoa: Text-figures $2 \mathrm{~d}$ (protozoan indicated by arrows) and $2 \mathrm{e}$ are simple sections and text-figure $2 \mathrm{f}$ is a $3 \mathrm{D}$ reconstruction of zone in text-figure $2 \mathrm{e}$.

The SEM-BSE images reveal interesting ultrastructural details of the fungi (text-fig. 3) and protozoa (text-fig. 4). Text-figure 3a shows a coenocytic, unbranched hypha with several buds resembling spores (arrowhead), similar to those observed by LM in text-figure $1 \mathrm{~b}$. Text-figure $3 \mathrm{~b}$ shows a similar hypha, transversely cut to reveal radial filaments (arrowhead) and buds (arrows). In text-figure $3 \mathrm{c}$, we can see the terminal branch apex of a hypha, while text-figure $3 \mathrm{~d}$ shows a hypha with constrictions transverse to the main axis (arrows) similar to those observed in text-figure $1 \mathrm{~h}$. The spatial relationship between hyphal apices and protozoa is shown in text-figure $3 \mathrm{e}$, in which sections of the protozoan (arrows) can be seen in close contact with the hyphae and hyphal apices (arrowhead). These hyphal apices present buds embedded in the fungal sheath (text-fig. 3f)

Text-figure 4a shows an amoeba with a temporary extension of its body, or pseudopod, (upper arrow) in longitudinal section in contact with the fungal wall (lower arrow). Text-figure $4 \mathrm{~b}$ shows a detail of the area described in text-figure $4 \mathrm{a}$. The hypha in contact with the amoeba has radial filaments but is devoid of buds. In contrast, text-figure $4 c$ shows a detail of the zone of contact between a protozoan and hypha (arrow) with spore-like buds. When examining flagellates, SEM-BSE allows the detailed observation of recurrent flagellum joined to the flagellate (text-fig. 4d, arrow). Text-figures $4 \mathrm{e}$ and $4 \mathrm{f}$ show a fungal hypha penetrating a protozoan, or perhaps, a fungus captured by a protozoan. The protozoan is indicated with an lower arrow and the fungus is marked with an upper arrow. Text-figure $4 \mathrm{f}$ is an image of a detail in text-figure 4e.

\section{Lithic substrate}

The images in text-figure 5 are SEM-BSE micrographs of sandstone samples from Linnaeus Terrace. Text-figure 5a is a general view, showing live microorganisms (arrows) among quartz grains (asterisks). Text-figure 5b shows a detail of the previous figure in which protists (microalgae) can be seen alongside fungi. Given the harsh conditions of the region, these microalgae, possibly Trebouxia, show some degree of plasmolysis (open arrow) and fungi show an altered ultrastructure (arrow). In text-figures $5 \mathrm{c}$-f, we provide images of a Linnaeus Terrace sandstone sample, but this time, containing fossil microorganisms. Text-figure $5 \mathrm{c}$ is an overview in which quartz grains (asterisks) may be distinguished and among these, pores, indicating zones where live microorganisms previously occurred and are now fossilized (open arrow). Empty pores could also be seen (black arrow) in which no microorganisms existed previously, or did exist but the permineralization process was unsuccessful leading to their disappearance. The high magnification image of microfossils in text-figure $5 \mathrm{~d}$ allows the identification of presumptive diatoms (arrow) and Trebouxia-type microalgae (open arrow). Text-figure 5e also shows these algae (open arrow) along with the fossil diatoms (arrow). The high magnification image in text-figure $5 \mathrm{f}$ shows a fossil microalga 6-8 ìm wide and 8-10 ìm long (arrow). Element distribution maps of these zones revealed high $\mathrm{Al}$ and $\mathrm{K}$ contents within and outside the fossil cells. The distribution map for Fe was similar, but a higher concentration was noted at the mi-

\section{TEXT-FIGURE 3}

SEM-BSE images of amber inclusions

a Coenocytic, unbranched hypha with several buds resembling spores (arrowhead); scale bar $=10 \mu \mathrm{m}$.

b Cross section of a coenocytic hypha revealing radial filaments (arrowhead) and buds (arrows); scale bar = $50 \mu \mathrm{m}$.

c Terminal branch apex of a hypha; scale ba $\mathrm{r}=10 \mu \mathrm{m}$. d Hypha with constrictions (arrows); scale bar $=10 \mu \mathrm{m}$.

e Protozoa (arrows) in close contact with hyphal apices (arrowhead); scale bar $=20 \mu \mathrm{m}$.

f Detailed image of hyphal apices with buds; scale bar $=$ $10 \mu \mathrm{m}$. 

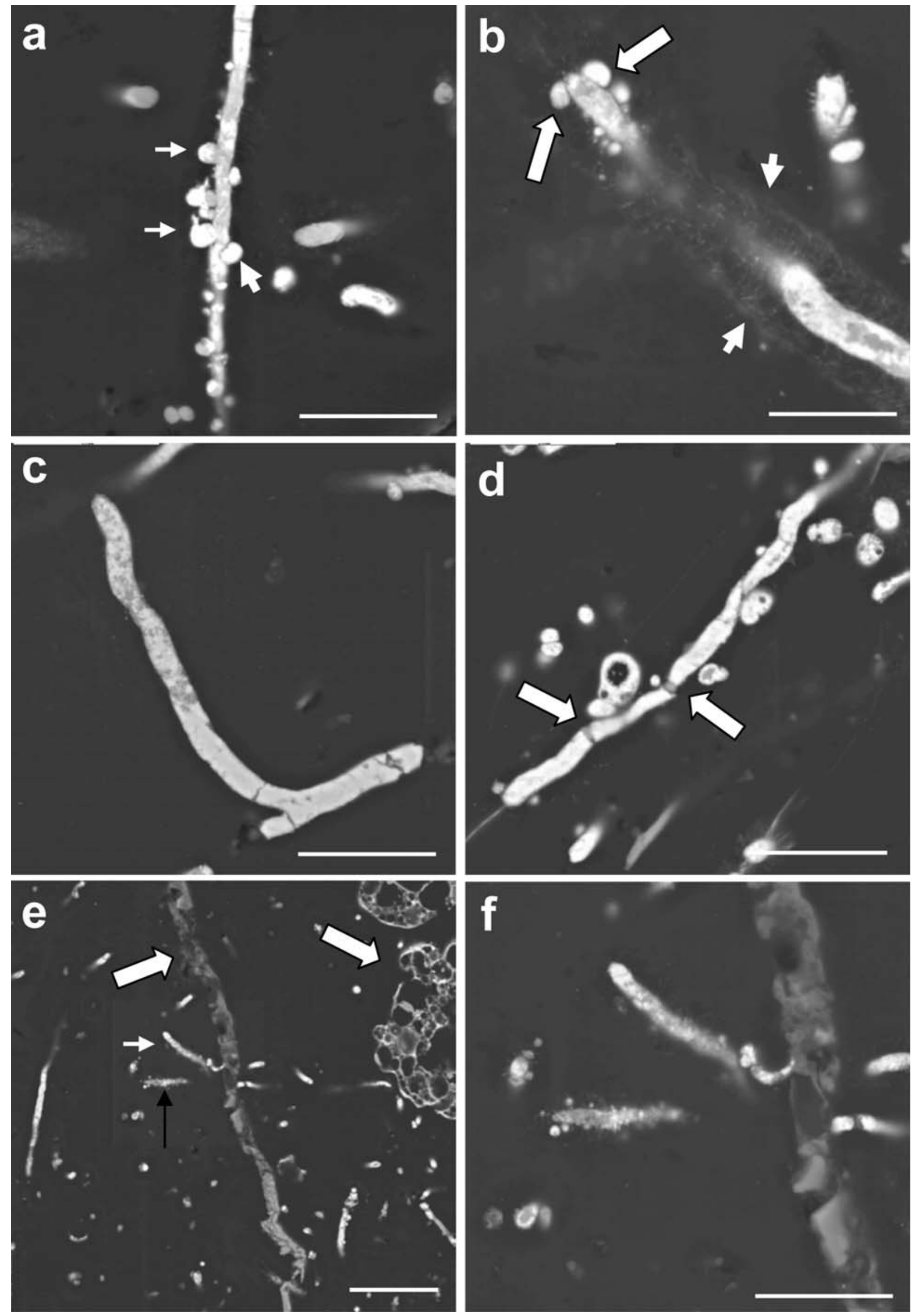
croorganism walls. Silica was weakly dispersed throughout the zones containing biological material and was obviously most intense in the areas where quartz grains surrounded the pore.

Text-figure 6 shows fossil protists in sandstone from Mount Fleming. The pore in text-figure 6a was seen to contain several cryptoendolithic permineralized microorganisms (arrows). In text-figure 6b, several algae (arrows) surrounded by fungi appear mineralized. The microalga indicated by an open arrow shows ultrastructural features that resemble thylakoids and lipid bodies. As it becomes mineralized, the alga marked with an asterisk in text-figure $6 \mathrm{~b}$, like the alga indicated by a star in text-figure $6 \mathrm{~d}$, shows the marked presence of crystals occupying the space in the centre of the cell that would have been the chloroplast. Text-figure $6 \mathrm{c}$ shows fossilized microalgae containing high amounts of Si inside, and high Fe levels in the area corresponding to the chloroplast periphery, peripheric cytoplasm and cell wall, observed as bright peripheral bands (arrow). Some cells were completely filled with $\mathrm{Ti}$ and $\mathrm{O}$ (asterisk). EDS profiles for this zone indicated relative concentration changes in $\mathrm{Si}, \mathrm{Al}, \mathrm{Na}$. Fe and $\mathrm{Ti}$ (data not shown). Text-figure $6 \mathrm{~d}$ shows a Si rich crystal, as can be seen in text-figure $6 \mathrm{e}$, in the core of the cells and details of membranes between this crystal and the cell wall. The distribution of Si can be seen in the map provided alongside the micrograph of the pore harbouring this alga. The element distribution maps for $\mathrm{Al}, \mathrm{Si}$, $\mathrm{S}, \mathrm{K}, \mathrm{Ca}$ and $\mathrm{Fe}$ highlight the particular presence of $\mathrm{Fe}$ and $\mathrm{K}$, along with $\mathrm{Al}$ and some $\mathrm{Si}$ around the central silica crystal (appearing as an intense bright spot in the Si map). This silica-rich crystal is located in what would be the pyrenoid and the central part of the chloroplast in the live alga. Thus, it seems that Fe, K, $\mathrm{Al}$ and some $\mathrm{Si}$ occupy the chloroplast periphery and the cytoplasm. Silica was also weakly detected in these parts but more so outside the cell. Ca was only found in the cell exterior.

The presence of S and Ca corresponds to gypsum, which envelops the microalgae Given there is some $\mathrm{K}$ and $\mathrm{Fe}$ outside the cells, jarosite may also be present.

\section{DISCUSSION}

All the protists found in the Álava amber were protozoa, including flagellate, amoeboid and ciliate forms, yet no protists such as microscopic algae and slime molds were found. The protozoa observed were accompanied by fungi but no prokaryotes, bacteria nor cyanobacteria could be detected around these. As text-figures $4 \mathrm{a}$ and $\mathrm{b}$ indicate, fungi seem to be closely associ- ated with amoebae. We also observed this behaviour in a previous investigation (Ascaso et al., 2003).

The microfossils of protists found in the Álava amber indicate they belonged to the microcenosis of a semiaquatic habitat. On the other hand, the lack of algal and cyanobacterial fossils fails to suggest a permanently wet, semi-aquatic susbtratum (Rikkinen and Poinar 2001). The presence of the genera Amoeba and Paramecium was confirmed by LM. We were also able to identify Astasia (Euglena), Amebas limax and the colpodid ciliate Pseudoplatyophrya nana. The SEM-BSE technique applied revealed ultrastructural details of the flagellates and details of flagellum insertion (text-fig. 4d). The first LM description of fossil zooflagellates was made by Schönborn et al. (1999), while Ascaso et al. (2003) provided SEM-BSE images of flagellates from Álava amber. Both Schonbörn et al. (1999) and Ascaso et al. (2003) provided the first images of palaeo-flagellates.

Despite having observed ciliates by LM (such as the Paramecium shown in text-fig. 2 b), no ciliates could be easily identified using SEM-BSE, probably due to the loss of their cilia once trapped in the resin that would eventually form the amber. Conventional SEM-SE has yielded useful data for the taxonomy of ciliated protozoa in aqueous media (Foissner 1991). Based on this technique, it has been possible to 3-dimensionally reconstruct the oral apparatus of ciliated protozoa (Hofmann-Münz et al. 1990), but this invariably involved removing the organisms from the aqueous medium in which they lived. As mentioned above, it is likely that when embedded in amber, ciliates lose their cilia. Moreover, it is impossible to remove them from the amber without damaging their ultrastructural elements. Schombörn et al. (1999) identified Paramecium species in fossil amber whose length:width ratio, highly characteristic body shape and similarities to related species and to those of the present paper indicate they are congeneric organisms.

When cells were mineralized, SEM-BSE revealed ultrastructural details of the cytoplasm in the three protozoan groups (except the presence of cilia). Non-mineralized protozoa preserve their autofluorescence signal and this gives rise to interesting confocal microscopy images. Further, CLSM enables the detection of partly- or non-mineralized fungi. Single confocal sections (text-figs. 2d,e) allow the observation of some ultrastructural elements of cells, and serial confocal sections serve to obtain sufficient data for $3 \mathrm{D}$ reconstruction. The $3 \mathrm{D}$ images give some idea as to what extent fungal cells are spa-

TEXT-FIGURE 4

SEM-BSE images of amber inclusions

a Amoeba with pseudopods (upper arrow) in contact with fungal wall (lower arrow); scale bar $=10 \mu \mathrm{m}$.

b Detail of the area of contact between amoeba and the fungal wall in text-figure $4 \mathrm{a}$ (arrow); scale bar $=5 \mu \mathrm{m}$.

c Contact (arrow) between protozoa (star) and hyphae (asterisk); scale bar $=10 \mu \mathrm{m}$. d Flagellate with recurrent flagellum (arrow); scale bar $=20 \mu \mathrm{m}$.

e Fungal hypha (right arrow) penetrating a protozoan (left arrow); scale bar $=10 \mu \mathrm{m}$.

f Detail of the image shown in text-figure 4e. Fungal hyphae (arrowhead) and protozoa (arrow); scale bar = $5 \mu \mathrm{m}$. 

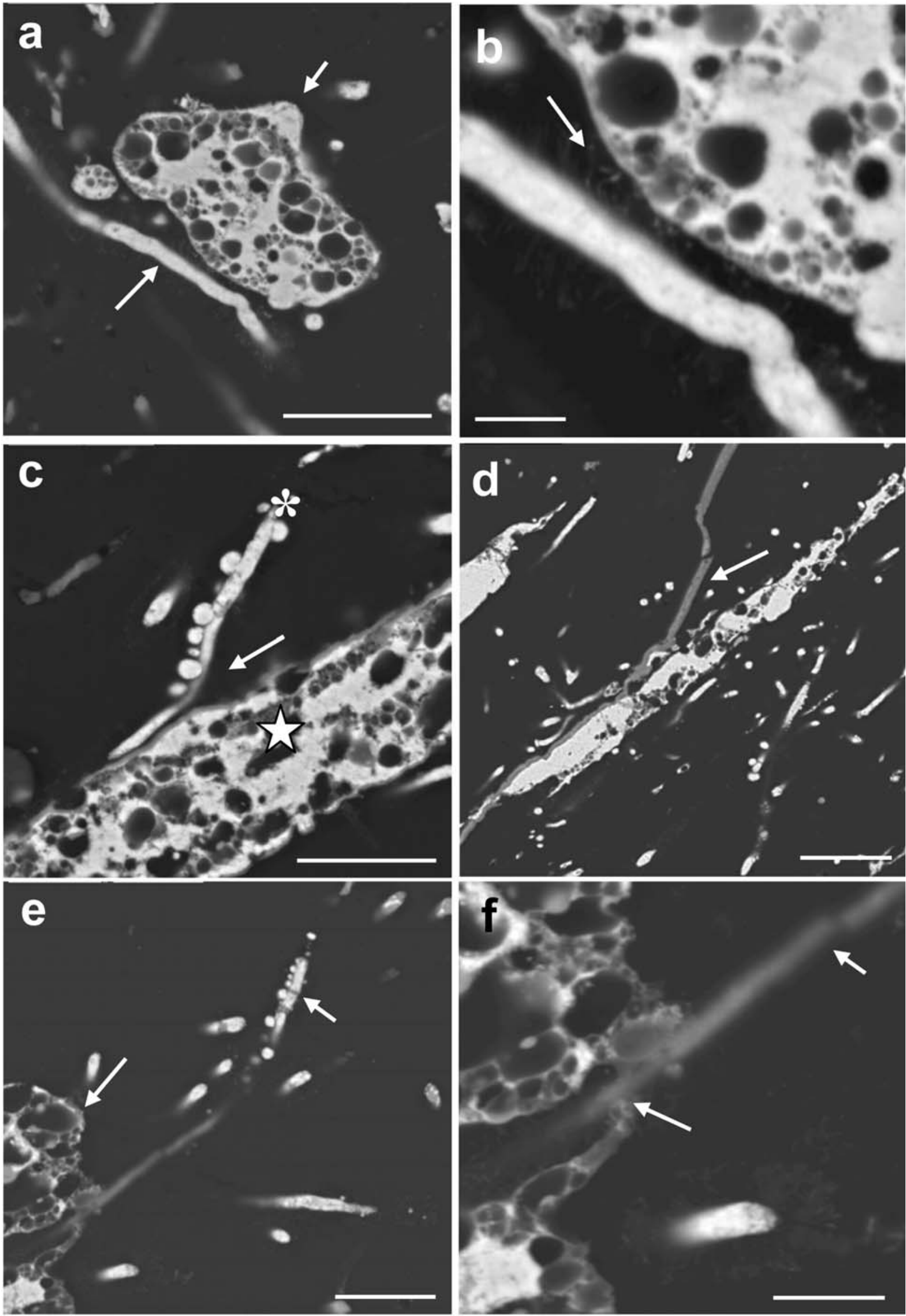
tially related to the protozoa in different zones of the amber. In some areas, only protozoa appear after 3D reconstruction (thus text-fig. $2 \mathrm{f}$ shows no fungal cells). The autofluorescence response (signal intensity) provides significant information on the greater or lesser degree of mineralization or, in other words, on the state of preservation of natural fluorochromes. When examining protozoan and fungal ultrastructure in amber, the CLSM and SEM-BSE techniques complement each other; the former detects the signal emitted by non-mineralised parts and the later picks up the signal from mineralised components.

In this study, the cytoplasm of fungi seemed to be fully mineralized and therefore showed-up brightly in the SEM-BSE images (text-figs. 3a-d and text-figs. 4a,b,e). In another zone of the same sample, the fungi were not mineralized and thus preserved some autofluorescence clearly revealing wall structure by confocal microscopy (see text-fig. 2c). The qualitative and/or quantitative microanalysis (EDS) of the chemical elements in the inner structure of fossilized microorganisms embedded in amber indicated the presence of $\mathrm{Fe}$ and $\mathrm{S}$, providing information on biomineralization and fossilization processes.

Some of the more abundant fungal hyphae inclusions observed by LM and SEM-BSE appear to be largely coenocytic, allowing their assignment to specific groups of fungi. It could even be that, not having combined the techniques LM, FM, CLSM and SEM-BSE, to date, mycologists have not been able to explore fungi in amber in sufficient depth. Although current fungi are extremely diverse, so far, very few genera have been identified in fossil resins since it is often difficult to identify their reproductive structures using conventional techniques (Pirozynski 1976; Rikkinen and Poinar 2001).

Hyphae were often endowed with radial structures that showed up brightly on SEM-BSE due to their high S and Fe contents. It was these fungi with numerous buds, resembling present-day aquatic fungi that were found closest to the protozoa. Generally these were amoebae, and it was these radial elements that made intimate contact with the protozoan (text-figs. 4a,b). Although, we are not in a position to interpret interrelations between the protozoa and fungi detected in amber from Álava, we are confident that future surveys will shed some light on this issue.

The first descriptions of fungal inclusions in rock substrates refer to observations made in Antarctic sandstones and are very recent (Wierzchos and Ascaso 2002). Studies of fossilized microbiota in Antarctic lithic substrates have mainly focussed on microalgae (Wierzchos and Ascaso 2001; Ascaso and Wierzchos 2003).

In the present samples from Linnaeus Terrace, interesting comparisons can be made between sandstones containing live microorganisms and those harbouring fossil microorganisms, since both of these types of sample may be found. In Linneaeus Terrace sandstone containing live microorganisms, quartz grains were loose, exposing fissures and pores among the grains that were occupied by living algae and fungi. However, given their ultrastructural appearance, the physiological state of the microbiota was not optimal. Sandstones from this region with fossil microorganisms showed quartz grains that were tightly bound to each other (text-fig. 5c). In SEM-BSE images, pores showed whitish patches as the result of the high atomic number of permineralized microbial masses. In samples from Mount Flemming, in which mineralized microorganisms were observed in all the samples examined, quartz grains were so tightly bound that they were often indistinguishable. However, the fossilization process in Mount Flemming often manages to perfectly preserve the ultrastructural features of microalgae. The Mount Fleming microalga fossil shown in text-figure 6d, has kept all its ultrastructural details including the inner chloroplast area normally occupied by the pyrenoid. This zone is very rich in $\mathrm{Si}$. These ultrastructural details and the presence of a central area in the cell of high Si content, are similar characteristics to those shown by a fossil microalga, also from Mount Fleming, described in one of our previous studies (Wierzchos and Ascaso 2002). Mount Flemming harbours a further type of alga, also with a well-preserved ultrastructure as shown in text-figure $6 \mathrm{~b}$. We are aware that given the complexity of the permineralization process, only if we are really lucky will we be able to see membranes (chloroplast envelopes or thylakoid membranes) in samples from Mount Fleming, yet these processes do occur. In contrast, in Linneaeus Terrace, where we managed to find habitats with live algae, the ultrastructural preservation of fossilized algae is less perfect. The high Fe contents of presumptive diatoms fossilized in Linnaeus Terrace (text-figs. $5 \mathrm{~d}, \mathrm{e}$ ) is striking. The deposition of silica in the Mount Fleming algae principally occurs in the central area of the extant cell chloroplast, a central chloroplast that contained a pyrenoid in which the cell stored rubisco. It is precisely this pyrenoid zone that, when fossilized, usually shows a crystal appearance with crests in which silica builds up. Peripherally to

\section{TEXT-FIGURE 5}

SEM-BSE images of Linnaeus terrace sandstone inclusions.

a General view showing live microorganisms (arrows) among quartz grains (asterisks); scale bar $=200 \mu \mathrm{m}$.

b Detailed view of an area in text-figure 5a showing microalgae (possibly Trebouxia), (open arrow) and fungi (arrow); scale bar $=10 \mu \mathrm{m}$.

c Sandstone (asterisks) containing fossilized microorganisms in pores (open arrows). Black arrows point to empty pores; scale bar $=200 \mu \mathrm{m}$. d Algae (open arrows) and presumptive diatoms (white arrow) fossilized in sandstone pores.; scale bar = $20 \mu \mathrm{m}$.

e Algae (open arrows) and presumptive diatoms (white arrow) fossilized in sandstone pores; scale bar = $20 \mu \mathrm{m}$.

f Fossilized microalga (arrow) showing ultrastructural details; scale bar $=5 \mu \mathrm{m}$. 

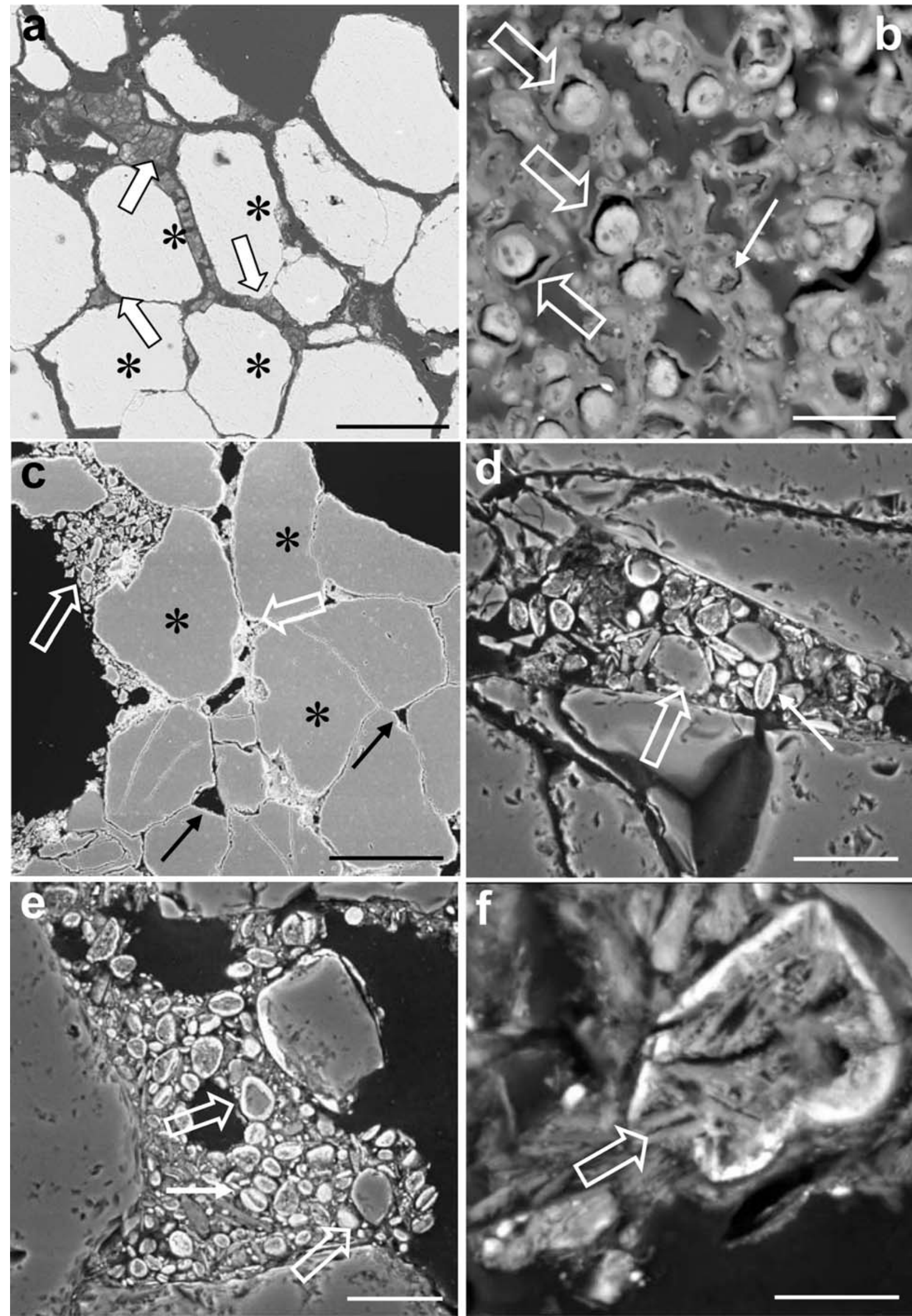
this crystal, areas corresponding to the rest of the chloroplast and surrounding cytoplasm were observed. These regions show a notable drop in $\mathrm{Si}$ and increased levels of $\mathrm{Al}, \mathrm{K}$ and sometimes $\mathrm{Na}$. Iron was detected, its intensity increasing as the cell wall was approached. Oxygen always accompanied each of the elements detected. The elements $\mathrm{Ca}, \mathrm{S}$ and $\mathrm{O}$ principally, and to a lesser extent $\mathrm{K}$ and $\mathrm{Fe}$, appeared surrounding the microalgae and their associated fungi in the Mount Fleming sandstone. These elements correspond to gypsum enveloping the microbiota and may even reflect the presence of jarosite $\left[\mathrm{KFe}_{3}\right.$ $\left.\left(\mathrm{SO}_{4}\right) 2(\mathrm{OH})_{6}\right]$. Our research group previously detected jarosite by X-ray diffraction (Wierzchos and Ascaso 2002) in the matrix around fossilized cells.

In sandstone from Linnaeus Terrace, fossilized algae showed no central core containing $\mathrm{Si}$, and the entire cell appeared to be completely filled with $\mathrm{Al}, \mathrm{K}$ and $\mathrm{Fe}$, with Fe most intensely observed within the algal wall. The elements were also found outside the cells, where no $\mathrm{S}$ or $\mathrm{Ca}$ were detected as in Mount Fleming. The weak presence of $\mathrm{Si}$ was noted in- and outside cells.

When we compare the mineralization patterns observed for the two regions, Mount Fleming and Linnaeus Terrace, there are two outstanding features: the Si core does not seem to occur in the Linnaeus Terrace fossilized cells, which could be explained by the algae possibly not having pyrenoids, but elements such as $\mathrm{Al}, \mathrm{K}$, and $\mathrm{Fe}$ are found in the cell cytoplasm and Fe is deposited at cell walls. This preference of Fe for the walls is such that in other pores of Mount Fleming sandstone, ultrastructural details were not detected in the algae (text-fig. 6c) but they could be identified through their morphology by comparing them with those previously described for the same region, and above all through their mineralization pattern, in which the localization of $\mathrm{Fe}$ provides essential information. The algae cited show large amounts of Fe localized peripherally in the cell interior, close to and at the wall. In their interior, the algae mainly show high $\mathrm{Si}$ levels (reminiscent of the $\mathrm{Si}$ core of the microalgae in text-fig. 6b, asterisks, and 6d, star), but also contain $\mathrm{Al}, \mathrm{Na}$ and $\mathrm{K}$. In these pores, cells completely filled with titanium were observed. These therefore had no $\mathrm{Si}, \mathrm{Al}, \mathrm{Na}$ or $\mathrm{K}$ in their interior, but their periphery was still very rich in $\mathrm{Fe}$.

In this report, we show how when the cell ultrastructure is well-preserved (as in the images shown in text-figures $6 \mathrm{~b}$ and 6d) this is the best criterion of biogenicity. If this is not the case, permineralization patterns complemented with a morphological description (since ultrastructure is unknown) along with a chemical analysis on the nanoscale can, according to Conrad and Nealson (2001), be an excellent approach to evaluating the fossil evidence. As observed here, sandstone rocks may show several possible mineralization patterns for the different groups of microorganisms. In turn, these patterns -essential for understanding whether what we are looking at is an entire microorganism or only a fragment of fossilized microorganism- could depend on the particular environment surrounding the microorganisms during their fossilization.

Previous studies on the live microbiota of granite have provided us with knowledge on combined geophysical/geochemical actions occurring in the laminar minerals of granite (de los Ríos et al. 2002). In this substrate, the presence of cyanobacteria sometimes gave rise to a low $\mathrm{pH}$ (de los Ríos et al. 2003) which, in turn, could induce the bioweathering of these laminar minerals. Once bioweathering and biomobilization of elements has commenced, protists and fungi may gain access to elements which, in the appropriate conditions, might lead to cell permineralization, perhaps after their decay and/or death. In some instances, these biomineralization processes may result in the inorganic preservation of microorganism cells and give rise to microbial fossils.

\section{ACKNOWLEDGMENTS}

We sincerely thank E.I. Friedmann for antarctic samples, F. Pinto, S. Lapole and R. Santos for technical assistance, A.T. Martinez and M. J. Martínez for the discussion of results related to fungi, Ana Burton for translating the manuscript and Carmelo Corral. This study was funded by the projects: Proyecto Ámbar-2000 - Diputación Foral de Álava and Proyecto BOS2003-02418, REN2002-03542 and REN2003-07366$\mathrm{CO} 2-\mathrm{O} 2$ of the Plan Nacional I+D.

\section{REFERENCES}

ALONSO, J., ARILLO, A., BARRÓN, E., CORRAL, J. C., GRIMALT, J., LÓPEZ, J. F., LÓPEZ, R., MARTÍNEZ-DELCLÒS, X., ORTUÑO, V., PEÑALVER E. and TRINCAO, P. R., 2000. A new fossil resin with biological inclusions in lower Cretaceous deposits from Álava (Northern Spain, Basque-Cantabrian Basin). Journal of Paleontology, 74(1):158-178.

\section{TEXT-FIGURE 6}

SEM-BSE images of Mount Fleming sandstone inclusions.

a Sandstone pores containing fossilized microorganisms (encircled by arrows); scale bar $=200 \mu \mathrm{m}$.

b Fossilized algae (arrows). Asterisks highlight algae with a homogeneously mineralized interior; scale bar $=5 \mu \mathrm{m}$.

c Sandstone pores containing fossilized microorganisms. The asterisk marks an alga containing titanium. The open arrow points to an algal cell containing iron in peripheral areas and silicon in the interior; scale bar $=20 \mu \mathrm{m}$.

d Pore detail showing algae with ultrastructural details such as chloroplast membranes and a silica crystal occupying the pyrenoid zone (star); scale bar $=5 \mu \mathrm{m}$.

e elemental distribution maps (EDS maps) of Al, Si, S, $\mathrm{K}, \mathrm{Fe}$ and $\mathrm{Ca}$ corresponding to the SEM-BSE image in text-figure $6 \mathrm{~d}$.; scale bar $=5 \mu \mathrm{m}$. 

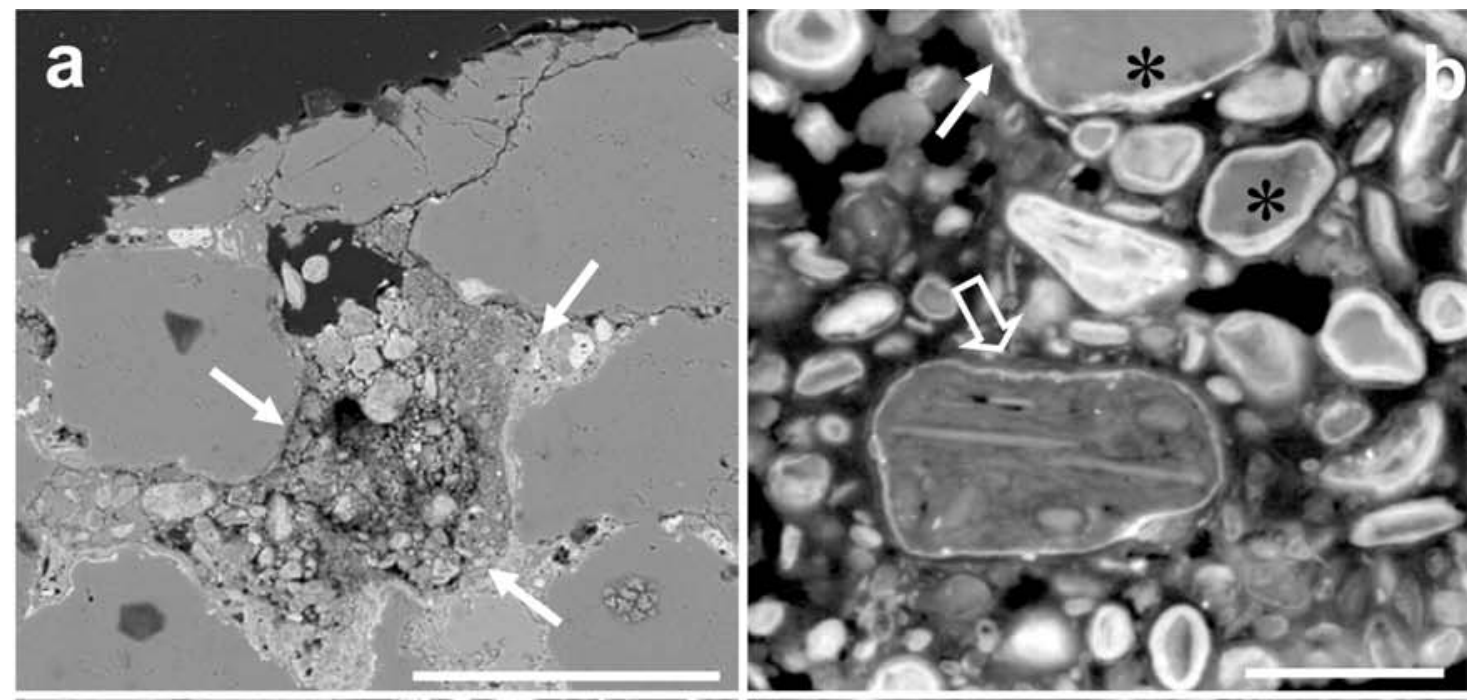

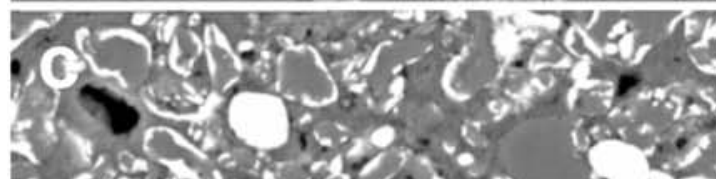

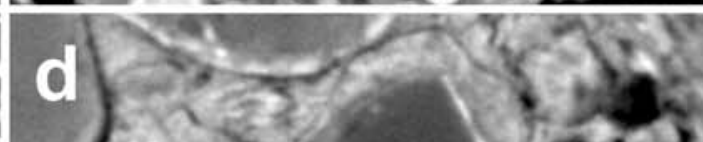
B. 6. (3)
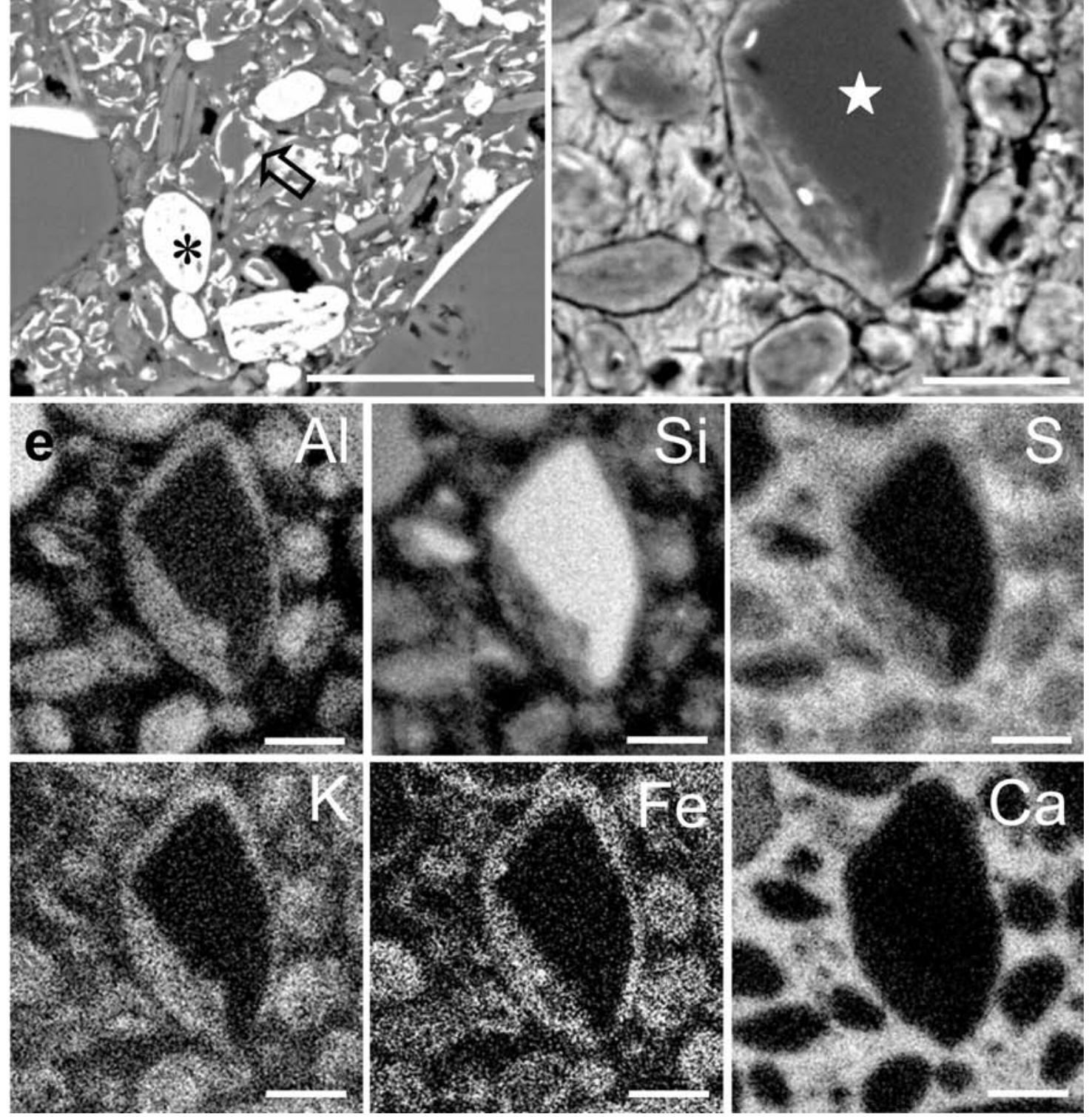
ASCASO, C. and WIERZCHOS, J., 2003. The search for biomarkers and microbial fossils in Antarctic rock microhabitats. Geomicrobiology Journal, 20:439-450.

ASCASO, C., WIERZCHOS, J., DE LOS RÍOS, A., 1998. In situ investigations of lichens invading rock at cellular and enzymatic level. Symbiosis, 24:221-234.

ASCASO, C., WIERZCHOS, J., CORRAL, R., LÓPEZ, C. and ALONSO, J., 2003. New application of light and electron microscopic techniques for the study of microbial inclusions in amber. Journal of Paleontology, 77:986-996.

CANO, R. J. and BORUKI, M., 1995. Revival and identification of bacterial spores in 25 to 40 million year old Dominican amber. Science, 268:1060-1064.

CONRAD, P. G. and NEALSON, K. H., 2001. A non-Earthcentric approach to life detection. Astrobiology, 1:15-24.

CORRAL, J. C., LÓPEZ DEL VALLE, R. AND ALONSO, J., 1999. El ámbar cretácico de Álava (Cuenca Vasco-Cantábrica, Norte de España). Su colecta y preparación. Estudios del Museo de Ciencias Naturales de Álava, 14:7-21.

DE LOS RÍOS, A., WIERZCHOS, J. and ASCASO, C., 2002. Microhabitats and chemical microenvironments under saxicolous lichens growing on granite. Microbial Ecology, 43:181-188.

DE LOS RÍOS, A., WIERZCHOS, J., SANCHO, L. and ASCASO, C., 2003. Acid microenvironments in microbial biofilms of Antarctic endolithic microsystems. Environmental Microbiology, 5:231-237.

FOISSNER, W., 1991. Basic light and scanning electron microscopic methods for taxonomic studies of ciliated protozoa. European Journal of Protistology, 27:313-330.

FRIEDMANN, E. I., DRUK, A. Y. and McKAY, C. P., 1994. Limits of life and microbial extinction in the Antarctic desert. Antarctic Journal of US, 29:176-179.

GRIMALDI, D. A., SHEDRINSKY, A. and WAMPLER, T. W., 2000a. A remarkable deposit of fossiliferous amber from the Upper Cretaceous (Turonian) of New Jersey, In: Grimaldi, D. A., Ed. Studies of fossils in amber, with particular reference to the Cretaceous of New Jersey. Leiden, The Netherlands: Backhuys Publishers 1-77.

GRIMALDI, D. A., LILLEGRAVEN, J. A., WAMPLER, T. W., BOOKWALTER, D. and SHEDRINSKY, A., 2000b. Amber from Upper Cretaceous through Paleocene strata of the Hanna Basin, Wyoming, with evidence for source and taphonomy of fossil resins. Rocky Mountain Geology, 35:163-204.

HOFMANN-MÜNZ, A.H., SCHOPPMANN, H. and BARDELE, Ch. F., 1990. The oral apparatus of Colpoda variabilis (Ciliophora, Colpodidae), I, 3-D reconstruction by serial semi-thin sections and low temperature scanning electron microscopy. European Journal of Protistology, 26:81-96.

JOY, D. C., 1991. An introduction to Monte Carlo simulations. Scanning Microscopy, 5:329-337.

KOHRING, R., 1995. Fossile Bakterien und Pilzsporen aus den Baltischen Bernstein. Neues Jahrbuch für Paläontologie, Monatschefe, 6:321-335.

LAMBERT, L. H., COX, T., MITCHELL, K., ROSELLÓ-MORA, R. A., DEL CUETO, C., DODGE, D. E., ORKAND, P. and CANO, R. J., 1998. Staphylococcus succinus sp. nov. isolated from Dominican amber. International Journal of Systematic bacteriology, 48(2):511-518.
NÉRAUDEAU, D., PERRICHOT, V., DEJAX, J., MASURE, E., NEL, A., PHILIPPE, M., MOREAU, P., GUILlOChEAU, F. and GUYOY, T., 2002. Un nouveau gisement à ambre insectifère et à végétaux (Albien terminal probable): Archingeay (Charente-Maritime, France). Geobios, 35:233-240.

PIROZYNSKI, K. A., 1976. Fossil fungi Annales Review of Phytopahtology, 5:237-246.

POINAR, G. O. Jr., 1992. Life in Amber. Stanford, California: Stanford University Press, 350 p.

POINAR, G. O. Jr., and THOMAS, G., 1982. An entomophtoralean fungus from Dominican amber. Mycologia, 74(2):332-351.

POINAR, G. O. Jr., and SINGER, R., 1990. Upper Eocene gilled mushroom form the Dominican Republic. Science, 248:1099-1101.

RAUTUREAU, M., COOKE, R.U. and BOYDE, A., 1993. The application of confocal microscopy to the study of stone weathering. Earth Surface Proceedings Landforms. 18:769-775.

RIKKINEN, J., and POINAR, G. O. Jr., 2001. Fossilized fungal mycelium from Tertiary Dominican amber. Mycological Research, 105:890-896.

SCHLEE, D. and DIETRICH, H. G., 1970. Insektenfürender Bernstein aus der Unterkreide des Lebanon. Neues Jarbuch fur Geologie und Paläontologie Monatschefe, 1:40-50.

SCHÖNBORN, W., DÖRFELT, H., FOISSNER, W., KRIENITZ, L. and SCHÄFER, U., 1999. A fossilized microcenosis in Triassic amber. The Journal of Eukaryotic Microbiology, 46:571-584.

SMITH, A. B. and AUSTIN, J. J., 1997. Can geologically ancient DNA be recovered from the fossil record? Geoscientist, 7(5):8-11.

STANKIEWICZ, B. A., POINAR, H. N., BRIGGS, D. E. G., EVERSHED, R. P. and POINAR, G. O. Jr., 1998. Chemical preservation of plants and insects in natural resins. Proceedings of the Royal Society of London. 256:641-647.

THOMAS, G. and POINAR, G. O. Jr., 1988. A fossil Aspergillus from Eocene Dominican amber. Journal of Paleontology, 62(1):141-143.

WAGGONER, B. M., 1994. An aquatic microfossil assemblage from Cenomanian amber of France. Lethaia, 27:77-84.

WIER, A., DOLAN, M., GRIMALDI, D. GUERRERO, R., WAGENSBURG, J. and MARGULIS, L., 2002. Spirochete and protist symbionts of a termite (Mastotermes electrodominicus) in Miocene amber. Proceedings of the National Academy of Sciences, 99:1410-1413.

WIERZCHOS, J. and ASCASO, C., 1994. Application of backscattered electron imaging to the study of the lichen rock interface. Journal of Microscopy, 175:54-59.

, 2001. Life, decay and fossilization of endolithic microorganisms from the Ross Desert, Antarctica: suggestions for in situ further research. Polar Biology, 24:863-868.

_ 2002. Microbial fossil record of rocks from the Ross Desert, Antarctica: implications in the search for past life on Mars. International Journal of Astrobiology, 1:51-59.

WIERZCHOS, J., ASCASO, C., SANCHO, L. G. and GREEN, A., 2003. Iron-rich diagenetic minerals are biomarkers of microbial activity in Antarctic rocks. Geomicrobiology Journal, 20:15-24.

Manuscript received January 3, 2004

Manuscript accepted March 11, 2005 